JELENA ANĐELKOVIĆ GRAŠAR

Institute of Archaeology

Belgrade, Serbia

j.andjelkovic@ai.ac.rs

EMILIJA NIKOLIĆ

Institute of Archaeology

Belgrade, Serbia

e.nikolic@ai.ac.rs
903/904:305-055.2

305-055.2:398.1

COBISS.SR-ID 264121100

Original research article

Received: April 15 2018

Accepted: April 30 2018

\title{
STEREOTYPES AS PROTOTYPES IN THE PERCEPTION OF WOMEN: A FEW REMARKS FROM HISTORY AND FOLK TRADITION
}

\begin{abstract}
The perception of women in past centuries has often been based on preconceived ideas, models and patterns of behaviour, all of which formed stereotypes concerning women. Many stereotypes originated in the patriarchal environment and according to Christian moral principles. Not even ladies from imperial circles were spared of being labelled with different stereotypes, one of the most frequent being their modest provenance, and of being called harlots, courtesans or prostitutes. This perception was later taken to a new, deeper level in the centuries-long folk tradition, where women, often of foreign origin, from notable families or in high positions in the state, were considered cursed or guilty for something that a man was not supposed to be blamed for. These women were the objects of many legends and were often associated with demonic creatures and considered fairies or witches.
\end{abstract}

KEYWORDS: STEREOTYPE, WOMAN, EMPRESS, COURTESAN, WITCH, FAIRY, DEMONIC CREATURE, HISTORY, LEGEND, FOLK TRADITION.

\section{INTRODUCTION ${ }^{1}$}

Stereotypes in the centuries-long perception of women in society go back to the distant past, i.e. to the time when Christianity as a religion was establishing models, standards and patterns of behaviour, and some of these stereotypes haven't changed to this day. Starting with the archetypal male fear of paralysing female powers connected to Medusa, i.e. the Gorgons, to horrifying executions of "witches" in the Middle Ages, all

1 The article is a result of the project: Viminacium, Roman city and military camp - research of material and non- material culture of inhabitants by using the modern technologies of remote detection, geophysics, GIS, digitalization and $3 D$ visualization (no 47018), funded by The Ministry of Education, Science and Technological Development of the Republic of Serbia. the way to the universal labelling of prostitutes, some of the stereotypes have been generally accepted in human language and conscience to the present day. Attempting to unravel at least some of the questions concerning stereotypes in the perception of women in society, in this short study we will look back at the origin of the appearance of the usual stereotypes, which can be tracked through the emergence and rise of Christianity, as well as through the forming of myths and legends in folk traditions, which, as we shall see, are based on historically generated stereotypes. 


\section{STEREOTYPES IN HISTORICAL SOURCES}

One of the first Christian reports of a negative image of a woman was one concerning Romula, Galerius' mother. Due to the notorious persecutions of Christians by Galerius in 303, Christian authors fostered a distinctively negative attitude towards the emperor and his mother, who was described as a superstitious woman, venerating mountain deities and organising daily sacrificial feasts in their honour, which is something that Christians refrained from and, therefore, this hatred towards Christians allegedly instigated her son to destroy them (Lact. De Mort. XI: 1-2). ${ }^{2}$ Surely, these descriptions and the negative attitude of Christian written sources need to be taken with caution, although architectural structures, as well as the ornaments from Felix Romuliana support the idea that Romula venerated the mountain deities Liber and Libera, i.e. Dionysus as the counterpart of Liber, the deity that occupies the central part in the iconography of artistic decorations of the Gamzigrad palace (Живић 2010: 107-140) (Fig. 1, a-c). It seems that the tendency towards a negative attitude of the authors from Antiquity in regard to empresses who were not of noble descent resulted in the creation of a specific form of venerating women, emperors' mothers, that began during the tetrarchy. The gradual occurrence of female figures in politics or in public events in the Empire, generally speaking, could probably be interpreted as a reaction to the dominance of male figures and the militaristic atmosphere during the era of "barrack emperors" (Valeva 2009: 67-76). However, Galerius used his mother to create a legend about his divine discordance with the god Mars. In this way he glorified himself as the new Romulus, so that he did not even mind that such a legend would publicly shame his mother for adultery. ${ }^{3}$ In the wake of the legend of Galerius'

2 See more on this in: Поповић 2010: 479-489.

3 Galerius' divine descent originates from the god Mars, who was his father, Romulus being his brother, and his mother Romula, just like Olympias, mother of Alexander divine conception, his mother Romula, becoming thus known as an adulteress, turned into the pivot of the glorification of the emperor's origin and his connection to Romulus, and even Alexander the Great. This fact, as well as the act of erecting a palace in his mother's honour, could testify that in Galerius' ideological concept of the cult of the emperor, the new Romulus, Jupiter and Heracles, the veneration of the mother figure also took the form of a cult, which could neutralise the negative image formed by the subjects, created by this legend or by the hostility towards Christians.

The first Christian empress, and one of the most famous, Helena, the mother of Constantine the Great, not only became a model of piety for all future Byzantine empresses, but was also celebrated as a saint. Although her origin was glorified and mostly based on myths in written sources from later periods, according to the importance that she gained with time (ASS Aug. III: 580599), in contemporary sources, Helena's name was associated with negative connotations. ${ }^{4}$ The negative attitude of contemporaries towards the empress' origin is visible in the allegations that she was an innkeeper, even a prostitute, and Constantine's rival Maxentius ridiculed him as a "son of a harlot", indicating that he was not worthy to be proclaimed Caesar (Lenski 2012: 62). According to Eusebius' assertions that she died at the age of eighty, after her pilgrimage to Jerusalem, it could be assumed that she was born around 248/9 (Euseb. Vita Const. 3.46.1). It is not known where and when Helena met Constantius Chlorus, but it is possible that they were never in an official marriage, but in some sort of concubinage, permitting a relationship between two partners from different social classes (Drijvers 1992: 17-19). Constantius found a politically more convenient choice of partner in Theodora, daughter of Augustus Maximi-

the Great, conceived him with the god himself, who approached her in the form of a dragon (Lact. De Mort. IX. 9; Epit. De Caes. 40, 16).

4 She was not only described as a waitress in an inn, but also as a prostitute. Concerning sources on this matter, see: Lenski 2012: 59. 

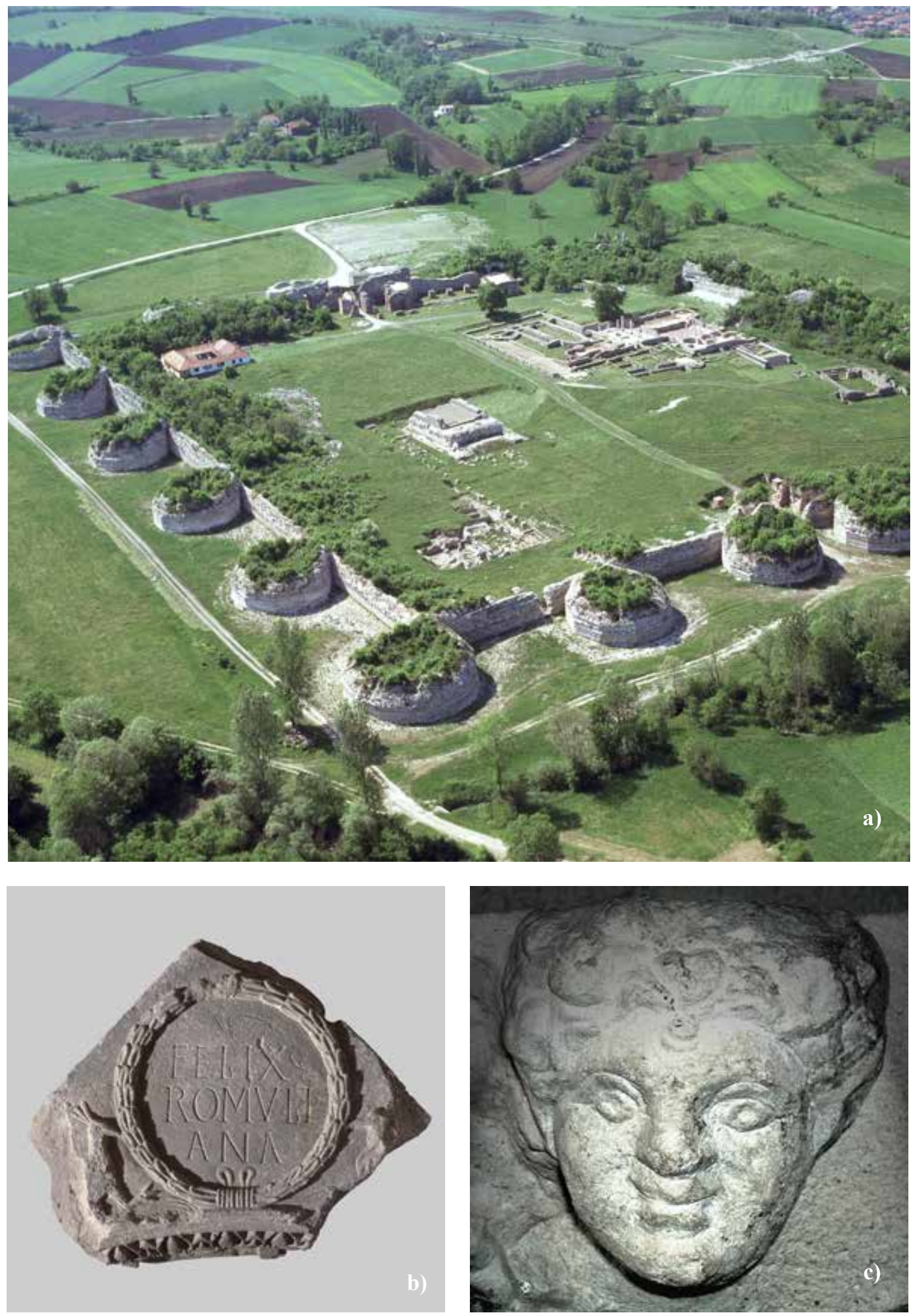

Fig. 1 - a) View of the Gamzigrad palace b) Inscription FELIX ROMULIANA on the discovered archivolt at the site c) Capital with the so-called portrait of Romula (Documentation of the Institute of Archaeology) 
anus, whom he married ca 289 (likewise, Galerius married Valeria for similar reasons), which permitted a closer relationship between the Augustus and the Caesar (Barnes 1982: 125-126). However, since Constantine was proclaimed Augustus in York, Helena became a significant support for her son and an active participant in religious matters (Drijvers 1992: 35-38). Having become one of the tetrarchs, Constantine, like his father before him, ruled from Trier (Augusta Treverorum), the city in which legends about Helena's noble descent started to develop, which is why it is presumed that it is here that the empress joined Constantine's court (Freisenbruch 2011: 211). Unlike Romula, who, according to historical sources, directly influenced Galerius' decision to persecute Christians by her veneration of mountain deities, Helena's support for Christians, as stated by written sources, was instigated by her son Constantine (Euseb. Vita Const. 3.47). As previously mentioned, since the time of the tetrarchy, the attitude of emperors towards their mothers became particularly emphasised, not only in some political or religious matters, but also in art. Thanks to the support that Helena had as the empress mother of the first Christian monarch, her modest provenance was quickly forgotten, and, aside from her rise to the higher status of Augusta in 324, the image created of her as a pious woman was even more important (Fig. 2). The shift in regard to her descent, thanks to her benefaction, the churches she had erected, her journey to the Holy Land and the legendary finding of pieces of the True Cross, contributed to the empress Helena acquiring the reputation of a great Christian and coming to be a role model to future Byzantine empresses, who, by their actions, became "new Helenas".

The empresses of the Theodosian dynasty, each in their own way, fulfilled the traditional ideal of imperial domination and, like the empress Helena, became models of good Christian be-

5 More on this in: Drijvers 1993: 85-90; Brubaker 1997: 52-75; James 2001: 14, 149-150, 153-154; Coon 1997: 97103, 118-119, 134-135; Herrin 2001: 1-2, 21.

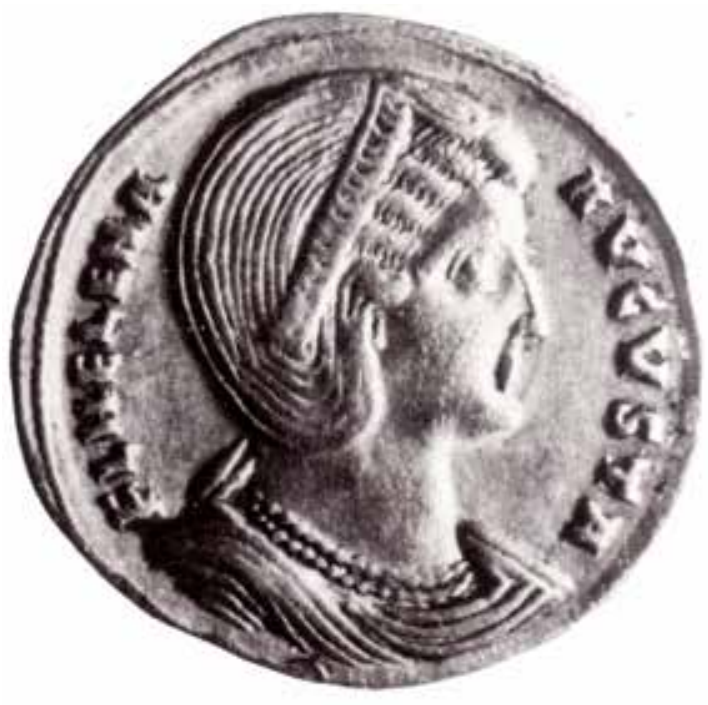

Fig. 2 - Solidus of the empress Helena from the National museum of Belgrade (After: Antički portret u Jugoslaviji 1987, 244)

haviour. ${ }^{6}$ However, at the beginning of the $6^{\text {th }}$ century, the question of the lowly origin of empresses was opened again, in one of the most well-known works of Procopius of Caesarea, Secret History (Historia Arcana).

Euphemia, the wife of the Emperor Justin I, was a Byzantine empress between 518 and 523/524. In light of Procopius' Anecdota, and considering his aversion towards women from the imperial circle, we discover that Justin, before reaching a high position in the army, married a former slave of barbaric origin and a concubine, Lupicina (Proc. Hist. arc. 6, 17). The meaning of this name can be linked to a word designating a prostitute, ${ }^{7}$ so that, shortly after Justin's installation on the throne, the members of the demos chose a more respectable name for the empress - Euphemia (Theophanes, Chronicle, A.M. 6011). If this name was chosen in honour of Saint Euphemia of Chalcedon, it can be presumed that, in this symbolic way, the newly elected emperor and empress declared themselves

6 More on this in the study on Theodosian empresses: Holum 1982.

7 The Latin noun Lupa is linked to the cult of the she-wolf who brought up Romulus and Remus, in whose orgiastic rituals during the festival of Lupercalia people celebrated the fertility of the annual cycle. Brothels across the Empire were called Lupernalia (Grahn 1993: 139). 


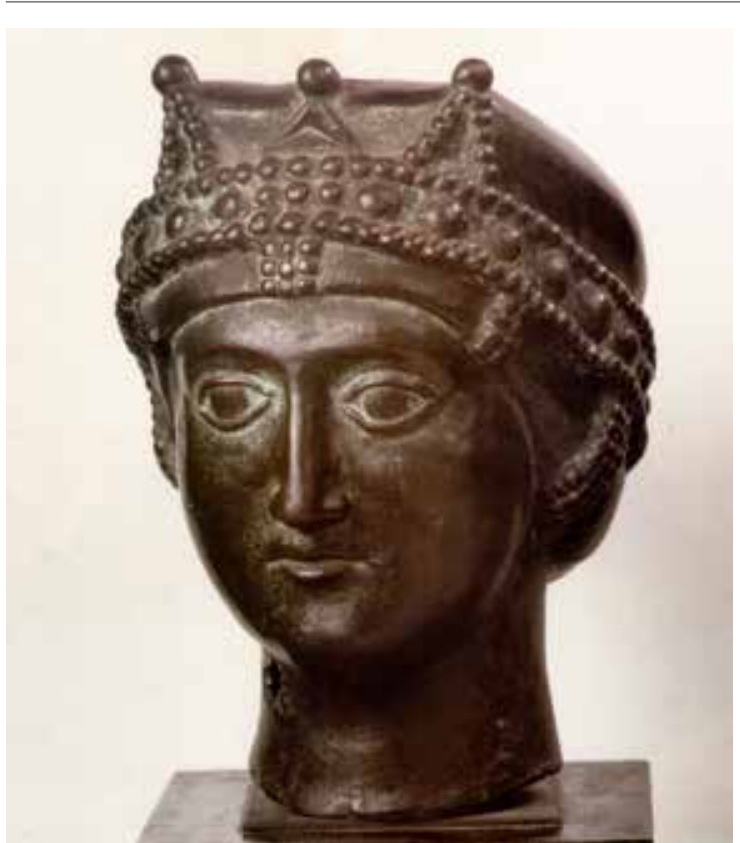

Fig. 3 - Bust of the empress Euphemia from the National museum of Niš

(After: Antički portret u Jugoslaviji 1987, 104)

as adhering to the orthodox principles, and thus put an end to the support of monophysitism by former emperors (Cameron 1976: 145). During her reign, empress Euphemia was known and celebrated as a devout and respectable Christian (Vasiliev 1950: 91). Her death could be dated in the same year or several years before Justin's abolition of the law that forbade marriage between a member of the senatorial class and an actress or a slave (in 524), which made the matrimony between Justinian and Theodora possible, which Euphemia was opposed to (Vasiliev 1950: 91, 98). Euphemia herself, as a former slave and concubine, was not subjected to the terms of this law, most probably because the emperor retroactively proclaimed her a free person since birth (Daube 1967: 385-386). Euphemia falls into the circle of empresses of lowly origin who gained respect as a notable Christian and pious empress (Fig. 3).

One of the best-known Byzantine empresses, Theodora (527-548), the wife of the Emperor Justinian I, has remained equally intriguing to scientists and the wider public to this day. Theodora's power was not as great as that of the former empresses Ariadne and Euphemia and her heir
Sophia, and the popularity that she gained later was mostly based on Procopius' Secret History (McClanan 2002: 121). According to Procopius' report on the empress' past, we discover that Theodora, as the daughter of an animal keeper, more precisely a bear keeper, belonged to the lowest rank of the Byzantine society, and that, after her father's death and subsequent poverty, became an actress, as well as a courtesan. ${ }^{8}$ After being a concubine of the governor of Lybia Pentapolis, she also engaged in prostitution in Alexandria and across the Middle East, and afterwards came back to Constantinople, where she met Justinian, became his mistress, and was elevated by him to the patrician status (Proc. Hist. arc., 9, 27-30). Theodora's connection to brothels is also expressed by her close friend and protégé, the monophysite bishop John of Ephesus (John Eph., Lives, PO 17. 188-9). Written sources also mention Theodora's frequent pregnancy terminations, as well as a son and a daughter born before her marriage to Justinian (John Eph., HE 2.11, 5.1; Proc. Hist. arc., 17.16-23). As mentioned above, the marriage between Theodora and Justinian was made possible by the introduction of a special law, and it could be dated into the period after Euphemia's death in 523 or 524. Theodora's influence on religious matters was mostly carried out through unofficial channels, while, according to written sources, Justinian's infinite love made her a dominant political and state governing partner, so that she was described as the emperor's co-ruler (Garland 1999: 29-30). Taking her cue from former empresses, Theodora's philanthropy encompassed the restoration and erection of many churches and monasteries, hospitals and orphanages, together with the Emperor Justinian or on her own, and the empress' benefactions included the protection of the monophysite community, especially women,

8 Procopius gives a detailed description of her services and her behaviour on stage: Proc. Hist. arc. 9, 3-26. Other sources concerning Theodora's youth give a more morally acceptable image of the empress and establish a new legend about the empress' origin; cf.: Evans 2002: 18-19; Evans 2011: 7-9. 


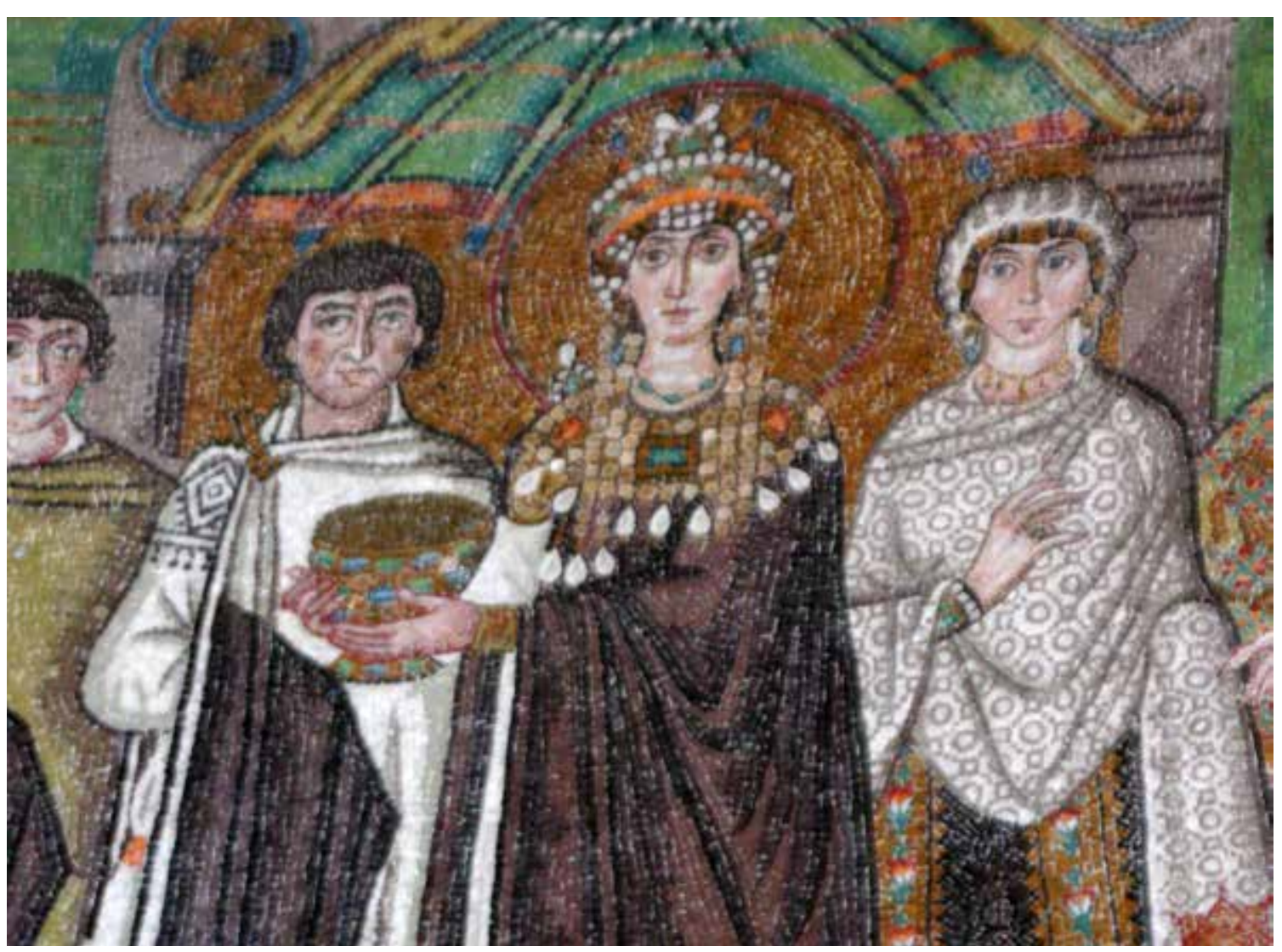

Fig. 4 - Mosaic depiction of the empress Theodora from the basilica San Vitale in Ravenna (photo by: N. Mrđić)

referring thus to her origin. ${ }^{9}$ The negative image of women loved by emperors seems to culminate in Procopius' Secret History and the historian's hostile tone in describing the empress Theodora. The empress' intriguing personality captured the imagination of later generations of researchers, artists and writers. Nevertheless, in many studies, the authors who treated the personality of the empress Theodora implemented their knowledge and pursued different approaches to this problem in order to revise the legendary image of her, established for centuries (Fig. 4). ${ }^{10}$ The precedent concerning the implementation of the law that permitted the wedlock of Justinian and Theodo$\mathrm{ra}$, as well as the empress' influence on the emperor's decisions, as in the case of the Nika riots, demonstrate the strong personality of this wom-

9 More on Theodora's beneficence and foundations, as well as on the attitude of the writers from Antiquity on this matter, in: McClanan 1996: 50-72.

10 Cf: Allen 1992: 93-104; Brubaker 2004: 83-101. an. ${ }^{11}$ Theodora is one of the rare examples in Byzantine history of a woman who started out as a dancer, from the lowest status, and arrived at the court, and who, as an outsider, unlike the empresses born in the purple and raised and prepared for the role of the Augusta, came to the position of power through marriage (Herrin 1993: 167-189). Just like Justinian erected Justiniana Prima in his mother's honour, following the model of his predecessors who honoured their respective mothers in a similar way, in the same way Theodora's well-doing and beneficence followed the tradition of the empresses from former dynasties; it is also important to emphasise her active involvement in resolving matters of women, especially prosti-

11 Theodora's intrepid personality showed when she dissuaded Justinian from abdicating and escaping during the Nika riot in 532, with the speech that she gave before the emperor and his councillors, using her legendary words: "The purple is a fine burial shroud". Procop. De bellis, . 1.24.33-37. 
tutes, which resulted in the official adoption of the law of protection of women in the famous Codex Justinianus (Garland 1999: 15-18).

\section{MYTHOLOGICAL PATTERNS IN CREATING THE IMAGE OF WOMEN IN LOCAL TRADITIONS}

Different interpretations of myths, legends, historical sources and images have, over time, led to the creation of patterns and models in folk tradition, according to which certain types of behaviour have been interpreted. Thus, Jerome A. Voss writes that archaeologists have excavated and examined many monuments during the last few centuries, but the history of their interpretation in folk tradition was much longer (Voss 1987: 80-85). Folk interpretations of monuments are usually different from their real function, due to the fact that people know very little or nothing about them and ignorance opens the possibilities to folkloric expressions of understanding nature and society, mostly associating the place with strange, supernatural or mysterious forces (Voss 1987: 80285). Although magical stories from oral folklore are impossible to explain by rational researchers, it seems that tradition, as a phenomenon that exists between reality and imagination, still reproduces a certain degree of truth (Koumarianou 2007: 171).

Some authors believe that legends are simply a continuation of traditions and rituals that began in the time when the monuments were being built, so they often attribute a significant complexity to ancient societies, based on present-day stories. Others think that the Christian connection to these places exists solely because they used to be important before Christianity. Ultimately, the only thing with constancy and continuity is the lore itself, which, although imperfect, conserves some traces of the past times. Imprecise knowledge enabled folk to find alternative and flexible explanations according to views and concerns belonging to their time, just like today, when the past is interpreted according to present habits and tendencies. Folklore teaches us about the way people ponder their history and helps us understand today's motivations and drives (Voss 1987: 80-85).

\section{Pavlovica and Jelica - antipodes of Christian ethics}

One of the most interesting legends of the Braničevo region in Serbia is set in the time of Prince Lazar, and is referred to in Serbian oral poetry, in a poem belonging to the non-historic cycle: "God Settles All Scores" (Радовановић 1997: 238). This legend is linked to several monasteries, springs and toponyms, among which are the monasteries Rukumija in the village of Bradarac, Sestroljin in the village of Poljana, Zaova and Bradača, also associated to the cult of sister Jelica, originating from this region (Бојковић, Ђокић 2016: 99-108). ${ }^{12}$

The lore associated with the origin of these monasteries is consistent with the aforementioned poem, recorded by Vuk Karadžić. According to the lore, not far from the place where the monastery of Zaova is situated today, two brothers lived, the noblemen Pavle and Radule Radić with their families, and their sister Jelica. The execution of Jelica, condemned by her brothers Pavle and Radule to be drawn and quartered by horses, after a false accusation by her sister-in-law Pavlovica, happened, according to the lore, on August $2^{\text {nd }} 1385$, on Saint Elias' Day. According to the poem, where a part of her body fell, a church appeared. However, according to a legend, a year after this event, when Prince Lazar heard of what had happened, he visited Jelica's grave - the spot where her head fell, above which he erected the monastery of Zaova, and in addition, three more monasteries: her chin generated the monastery of Bradača, her hand - the Rukumija monastery, and her eyes - the monastery of

12 More on this cult in: Спасић 1996: 219-226. 
Sestroljin. (Јовић 2014: 260-262). Leontije Pavlović also wrote about the cult of sister Jelica and recounted the legend about the origin of the four monasteries. According to this lore, the hill of Sopot was owned by the noblemen from the Radic family, vassals to Prince Lazar and, although they lived in Belgrade, they had a summer house on the hill. Pavle was also called the prince of Stig (Павловић 1965: 221). Field research shows that this lore still exists among folk (Јовић 2014: 260262; Павловић 1965), ${ }^{13}$ but only in the Braničevo region (Мирковић 2012: 15-17).

The existence of a hand as a relic in the Rukumija monastery was noted by Josif Veselić in the $1860 \mathrm{~s},{ }^{14}$ while Joakim Vujić and Milan Đ. Milićević make no mention of it. The previous hegumen of the monastery, Father Sava, recounted that he had a memory of this relic and that he used to come with his parents from Klenovnik to Rukumija to attend the service, at a time before World War I, and used to kiss this hand, which was partly coated in silver and placed in a wooden reliquary in the church. During the war, the hand disappeared, and rumour had it that it was taken away by the Bulgarians (Мирковић 2012: 10-12).

On the other hand, it is interesting to establish a link between the interpretation of the epic poem and the use of a spolia with the representation of Medusa built into the façade of the monastery in the $19^{\text {th }}$ century. Thus, even in the title of the poem itself, "God Settles All Scores", we can feel a certain warning. The poem relates a family harmony between the brothers Pavle and Radule and their sister Jelica, which was disturbed by the arrival of Pavlovica (Pavle's wife). Pavlovica, as a foreign element in the family unity, jealous of the love and attention that the brothers (her husband included) show to their sister Jelica, perpetrates a series of crimes in order to place the blame on her

13 This legend was also described by Josif Veselić in his work published in 1861, Monasteries in Serbia, 140-143.

14 Veselić wrote that in the church there was "a holy object, i.e. a hand of a holy person, generally believed to belong to that girl who was slain despite being innocent." Веселић 1861: 144. sister-in-law, from killing her husband's horse and falcon to murdering her own child. The brothers, misled by her accusations, sentence their sister to be drawn and quartered and, despite the injustice, Jelica accepts the verdict without complaint. From the standpoint of patriarchal and Christian ethics, Pavlovica's intention to "sow hatred" between the brother and the sister is recognised as a sin and adequately punished by illness. Although it is the brothers who killed Jelica, the transference of the sin of her killing to the sister-in-law can be interpreted in the spirit of traditional representations of the ambivalent nature and destructive powers of women, so Pavlovica's character is structured according to the model of a demonic female being (Бошковић 2005: 77). Furthermore, all the elements in the poem relating to Pavlovica and her punishment - the appearance of a lake as a chthonic place, the image of death caused by an illness lasting nine years, snakes as chthonic animals hatching inside her body or consuming her eyes, as an indication of blindness (i.e. witch's blindness) and her activities during night-time - indicate her demonic nature, and the murder of a child in the cradle opens the possibility of interpreting this character as a witch (Бошковић 2005: 79-80). As a consequence of all of the above mentioned, it could be expected that a woman without a personal name, known only by the female variation of her husband's name, Pavlovica, finds a visual representation in the image of Medusa, shown between two doves in a pediment, together with horsemen in the acroterion of a Roman marble stele, by no means fortuitously built into the southwest wall of the Rukumija monastery just beneath the cornice. However, though she is a demonic creature, Medusa's image has been humanised over the centuries and, in art, since antiquity, it has been considered as a significant motif because of its apotropaic purpose, so the folk interpreted the head of the female figure on the façade of the monastery as a personification of the unfortunate Jelica, and the horsemen as representations of her brothers (Milovanović, Anđelković Grašar 2017: 176-177) (Fig. 5). 


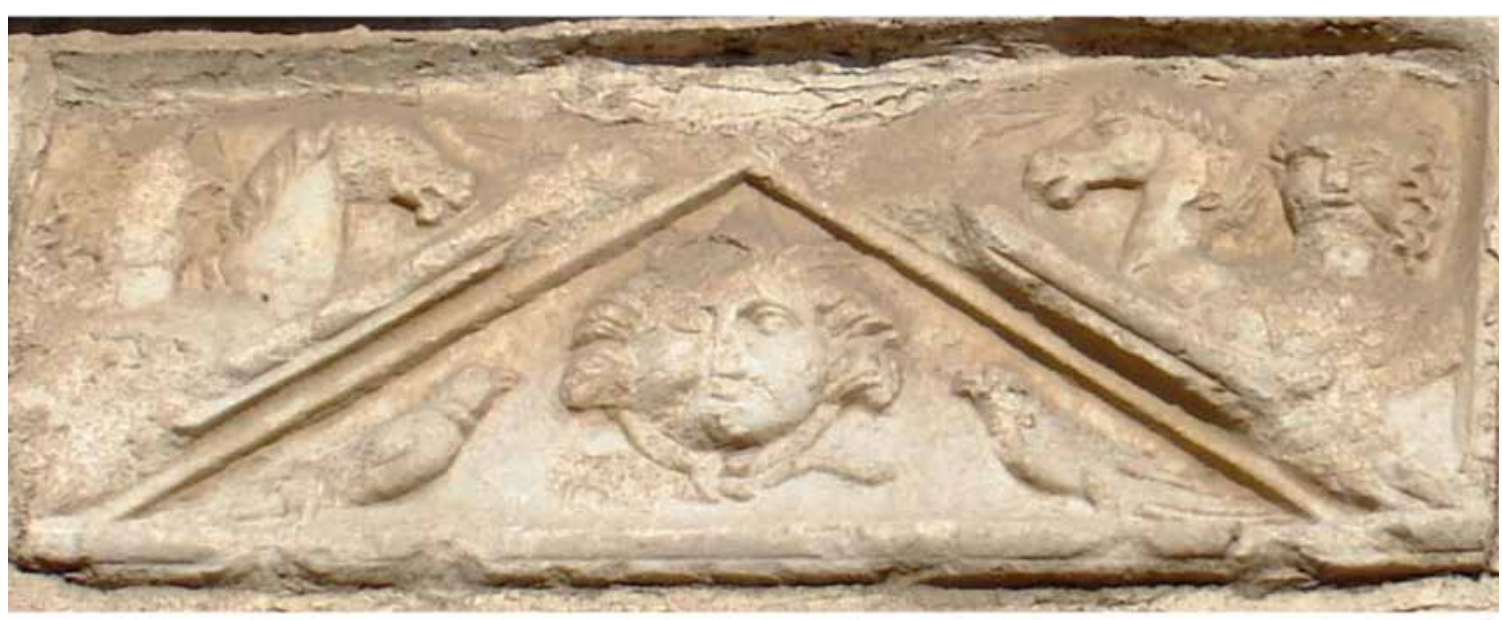

Fig. 5 - Spolia from the façade of Rukumija monastery with the depiction of Medusa and horsemen (After: Milovanović, Anđelković Grašar 2017, Fig. 19)

Another spolia with a representation of Medusa is associated with the Nimnik monastery. Since there is no reliable data concerning the time of the origin of this monastery in the village of Kurjače nor concerning its ktetor, it is assumed that it was built during the last decades of the autonomous Serbian state, as a foundation of some lower nobleman, and folk tradition ascribes it to Prince Bogoslav, a contemporary to Despot Đurađ Branković. In a piece of writing from 1734, Exarch John dates it to the time of Prince Lazar. In the Nimnik monastery there is a chapel named "Svetinja" with the grave of a holy man of unknown identity. According to the legend documented by Josif Veselić in 1861, hajduks killed a boy named Nikolaj, the son of a monk. The monks buried him, and later the hajduks built a house above the tomb. However, the house "turned into a chapel", so that "the folk still bring their ill here at any time of year, seeking help for various illnesses" (Веселић 1861: 147). “А family of hajduks still lives in the area and restores this tomb from time to time", writes Veselić (loc. cit.). Later stories about a little girl named Nikolina superseded the lore about the boy Nikolaj. The new hero is a Vlach girl Nikolina, killed by hajduks according to one version, or Turks according to another. Since the story of the hajduks is more widespread, it is probable that the lore originated in the $19^{\text {th }}$ century, when the term "hajduk" designated bandits who attacked anyone with money.
According to the lore, the hajduks went to pillage the monastery, but didn't know how to reach it. In a nearby Vlach village they came across a little girl who was guarding sheep and asked her where the monastery was. To every question, she persistently kept answering "Nu šću nimik", which, in Vlach language, means "I don't know anything". Later, when the hajduks found the church after all and pillaged it, a member of the hajduk gang who was the little girl's godfather said that she must have recognised him, so the leader ordered him to kill her. Since the girl never came home, the villagers went to search for her. In the distance they saw a bright light, and then the little girl's body on a tree, engulfed in flames. However, when they tried to take the oxcart carrying the girl's body, in the direction of the village, the oxen wouldn't move. Someone suggested they should head towards the monastery, the oxen started moving, so the little girl was buried next to the monastery. After penitence above her grave, her godfather built a chapel, and the monastery was named Nimnik, as a reference to the words that the girl repeated to the bandits. Thus, Saint Nicholas fell into oblivion and in his place the boy Nikolaj appeared, and later the girl Nikolina (Бојковић, Ђокић 2016: 90-92). The legend of the little girl's suffering was related in the poem "Holy Relic of the Nimnik Monastery". There are no written records concerning this poem, but it probably originated at the beginning 
of the $20^{\text {th }}$ century (Спасић 1998: 318). The other fragmented pediment of the Roman stele with Medusa's head was built into the lower part of the southern wall of the monastery of Nimnik (Fig. 6). Similar to the aforementioned example of the monastery of Rukumija, the memory of the unfortunate girl was evoked by the delicate and subtle image of the Medusa (Milovanović, Anđelković Grašar 2017: 177).

\section{Fairies}

Beliefs in imaginary beings with supernatural powers are deeply rooted across the entire region of northeast Serbia (Зечевић 1993: 257-258; 1981: 8-9). Cults - as the worship and veneration of a certain mythical subject (a plant, animal, force of nature, object, mythical being or a deceased person), as well as rituals that were performed as a set of rules and procedures within the cult itself and expressing veneration, secretly or publicly, represent an important element when researching the intangible cultural heritage of a specific area (Зечевић 1973: 43). According to Slobodan Zečević, eastern regions of Serbia keep a much clearer and fresher memory of demons than the western regions of the Dinaric Alps (Зечевић 1981: 6). He states that the church invested lots of effort into erasing the memory of pagan gods and idols and, thus, neglected the beliefs related to "lower mythology", i.e. demonic creatures, which could explain why local folk conserved more memories of demons than Slavic pagan deities. They did not reach the Serbs in their original form, but changed constantly under foreign influences and assimilations with the beliefs of other ethnicities (op. cit. 175-176).

Fairies as mythical beings, i.e. nature demons, exist in the beliefs of Slavic folk, as well as Germanic folk and people in Antiquity. According to Slobodan Zečević, they are pan European mythical beings, and in Serbia, the beliefs of the native population blended with those that the Slavs brought from their land of origin (op. cit. 9, 40). The fairies are exclusively female, and look like beautiful young girls, who often gather around springs to frolic, dance, sing and bathe. Their supernatural power lies in their hair or the garment that covered their head and wings on their back. It was believed that they could bring a dead person to life using medicinal herbs. However, their attitude to humans could be either friendly or malevolent, depending on their current mood, but also on the behaviour of humans towards them. A punishment of death or the deprivation of certain bodily functions was reserved for those who accidentally saw them bathing or enjoying some other pleasure, which was the ultimate transgression, because these events took place in locations that were taboo for mortals (op. cit. 41-43, 179).

Specific places in the landscape associated with different memories were based on certain elements of the environment that fascinated ancient societies, elements that people were familiar with or intuitively felt the presence of many generations. These places were often linked to rituals, and their spatial relationships, significance and functions mainly originated from certain historical values, common memories and the notions of origin and ancestry (Roymans et al. 2009: 338340). Almost as a rule, water was an accompanying element to cult places; the people attributed to water, especially spring water, healing effects and sacredness. Thus, numerous legends related to healing are present in the local population of specific regions, but there are also some places whose fame extends to a wider area. People visit them often, and in large numbers on certain holidays, when these places become "gathering places, fairgrounds and playing grounds" (Радовановић 1997: 237).

In the village of Rečica, near Kostolac, at the location whose toponym is "Dušnik"15 there is an

15 In the "Braničevo Journal" from 1467, Dušnik was listed as a village of six houses in Lučica Nahiye, and Momčilo Stojaković locates it west of the village of Biskuplje, noting that a hill named Dušnik still exists (Stojaković 1987: 192). It is the same location that 


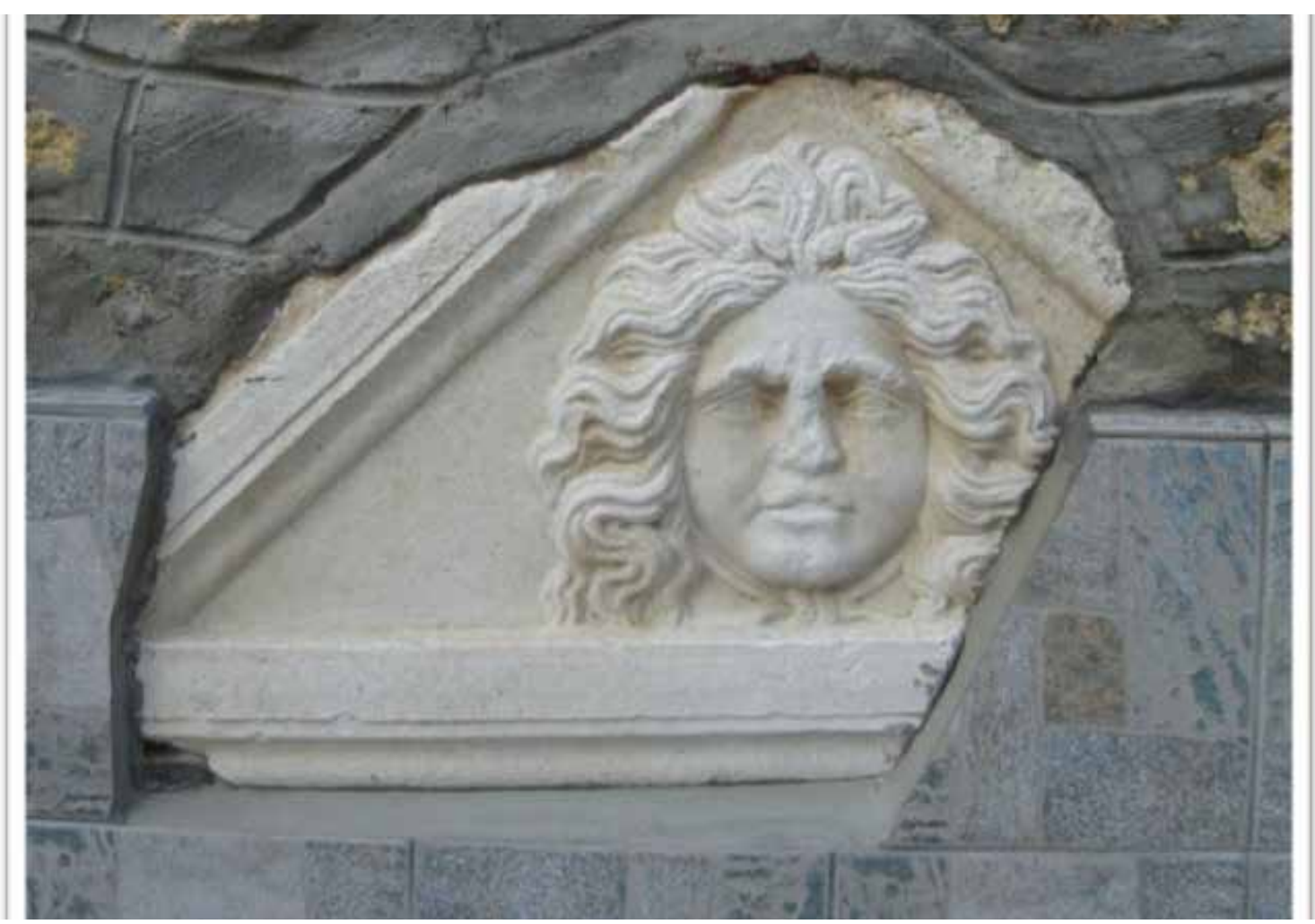

Fig. 6 - Spolia from the façade of Nimnik monastery with the depiction of Medusa (After: Milovanović, Anđelković Grašar 2017, Fig. 20)

acacia believed to have supernatural powers. Folk believe that every tree that differs from others by its size, appearance or position represents a potential residence of souls, spirits and mythical beings. A tree overgrown with vines is believed to be a "fairy tree". The acacia at "Dušnik" has a "fairy wreath" that sets it apart from other trees. It is believed that fairies gather around trees like this one and do harm to humans who hurt them. Thus, the tree itself is taboo as a fairies' meeting place, and any harm done to the tree would bring about the fairies' revenge. This belief system regarding "fairy trees" is a part of the traditional religious system of the Serbs (Ђокић, Јацановић 1992: 65).

"Svetinja" is a place on the left bank of the old riverbed of the Mlava in the village of Kostolac. It is considered sacred, the land is not supposed to be cultivated and it is forbidden to cut down trees in this location. In the central part there was an

Miljković and Krstić define as the area under Dušnik Hill, at the tripoint of the territory of the villages of Rečica, Kličevac and Kurjače (Миљковић, Крстић 2007: 134). elm, where people hung icons, and believed that this place had healing properties for many diseases. A lot of people, especially young women, from the entire area used to come here, wash their face, place offerings on the elm and light candles. Since the elm was situated on the rampart of a fortification from the Roman period, it withered with time, and cult functions were transferred to three smaller elms nearby. When archaeological excavations began at the site of "Svetinja", none of the locals wanted to remove the remains of the old elm, and scarcely anyone was willing to work on the excavation site. All the hardships that the archaeological team subsequently encountered were attributed by the locals to the archaeologists' activities in this area, where the existence of Roman, Early Byzantine and Slavic settlements with a necropolis have been confirmed (op. cit. 73). Some villagers believed that this was the exact spot where fairies lived and even used to choose some of the local inhabitants as spouses; these 
men would then visit this place during night-time. Incidentally, it is a common belief in Serbian demonology that fairies can have intimate relations with humans (Зечевић 1981: 9, 179). In the village of Kostolac, some residents believe that fairies also appear at two local crossroads. ${ }^{16}$

\section{Jerina}

The Despotess Jerina was the wife of the Despot Đurađ Branković; she was Greek, and her original name was Irene Kantakouzene. Her foreign origin in the country that found itself in difficult political circumstances, on the verge of being occupied by the Turks, carried negative connotations in the mentality of the folk, similar to the story of Pavlovica, who, as a foreign element in a family, destroyed the harmony between the brothers and their sister Jelica. Notwithstanding the feeling of closeness to the Greeks, which existed among the folk, thanks to the Orthodox religion, in traditional culture, any foreigner was equated with the category of foreignness, associated with evil and demons (Коњик 2006: 59). Thus, in folk poems, the Despotess Jerina, as a foreign woman, was described as a damned person, blameworthy of family misfortune and the political ruin of the Despotate and, furthermore, her powerful role of a woman who surpasses the household sphere certainly contributed to the negative image created in poetry. The folklore not only emphasises her arrogance in constraining the people to forced labour for building medieval edifices, but also imputes to her the frequent company of young men that she took as lovers and then killed, until finally one of them, Đurad, became her husband. These stories created a message conveying unacceptable behaviour, which could be transmitted from generation to generation (Гузина 2011: 84-85). This way of establishing a negative image and memory of this woman was deepened in oral poetry about the Branković family, where Jerina and her

16 According to the stories of locals. daughter Mara Branković were described as the damned female part of the family and accused of blinding Grgur and Stefan. In these poems, Jerina is also considered as being solely responsible for the marriage of her daughter to a Turkish ruler, an infidel; namely, the absence of men in contracting this marriage meant failing the patriarchal norms, which by default announced trouble and misfortune (Стамболић 2017: 222-224).

The names of two towers of the despot's court are associated with Roman sculptures which were built into them: "Jerina's Tower" was named after a statue of a Roman goddess situated in the niche in the first tower at the court entrance, in which the medieval population "recognised" the Serbian Despotess Jerina; and "Jezava Tower", i.e. "Nine Brothers' Heads Tower" and "Seven Brothers' Heads Tower", named after built-in sculptures taken from Roman tombstones (Цветковић 2009: 2931) (Fig. 7). Petar Popović indicates Roman sarcophagi, sculptures, plates with inscriptions and architectural fragments, and highlights the aforementioned statue of a Roman goddess, saying that "every good Serb had a duty to throw a stone at it, because it was believed that the figure represented the Damned Jerina, so in this way they would take revenge for the forced labour of their ancestors during the construction of this fortress. The villagers were even supposed to use their own carriage and oxen and the labour took so long that Old Man Novak had to rebel and join the hajduks" (Поповић 1931: 52). ${ }^{17}$ "The poor Despotess Jerina - Irene - they laid all the blame on her, as a Greek, believing that the wise and good Đurađ wouldn't be so heartless" (op. cit. 52-53). In order to justify the actions of their ruler, the folk laid the blame on the foreign woman, his wife. During the bombing in World War I, the sculpture of the goddess fell down and broke, revealing an inscription on the back of the pedestal, copied by a certain $\mathrm{Mr}$ Milijević, but the copy was ruined during the war.

17 This shows how folk legends are often a blended mixture of events and characters. Namely, Old Man Novak was born in the $16^{\text {th }}$ century, so he couldn't be a contemporary of the construction of the Smederevo fortress. 


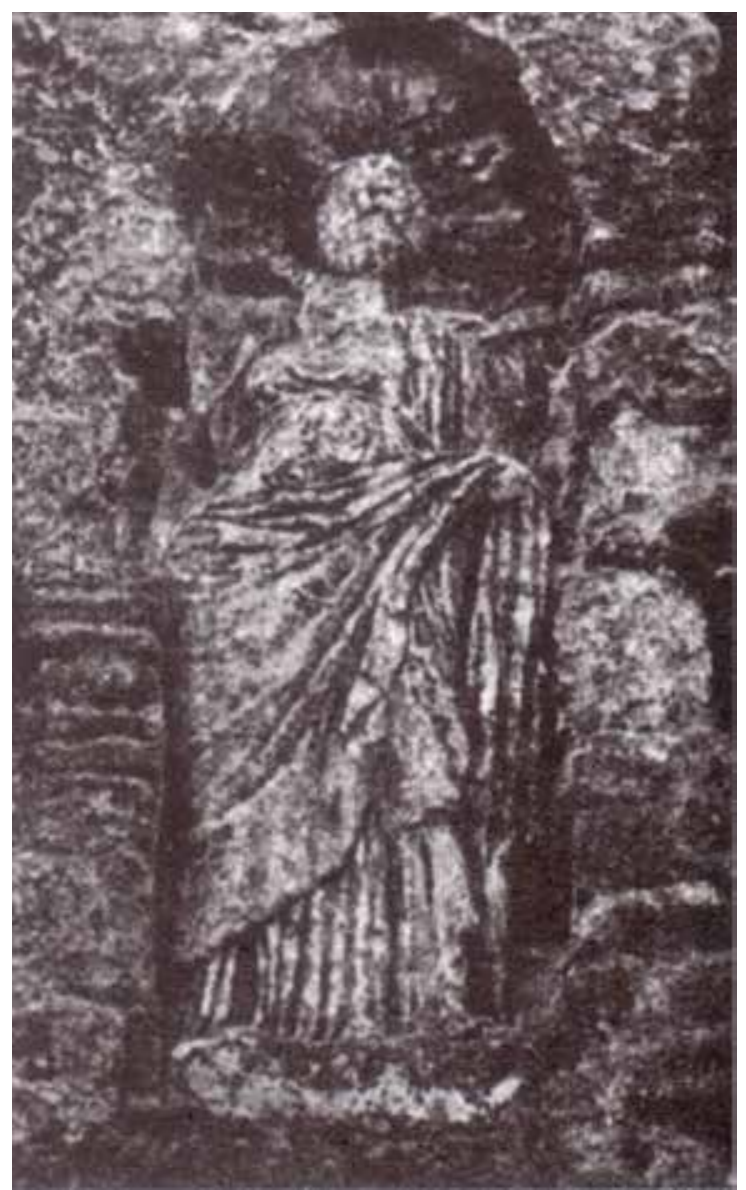

Fig. 7 - Sculpture of the Roman goddess Vesta, so-called Jerina, spolia from Smederevo fortress (After: Цветковић 2009, 32)

The fallen sculpture, as well as others assembled in one place in Veliki Grad, was taken away by the occupiers (op. cit. 53). ${ }^{18}$ Negative associations to the unfortunate despotess still live among the Serbian folk in the saying: "Evil deeds were done by Đurađ's Jerina, she did evil but lived to see worse" (Гузина 2011: 84). Outside of folk tradition, historically speaking, the Despotess Jerina's destiny was not any better. She died a year after Despot

18 An interesting story about the interest of foreign armies in antiquities in Smederevo is related in an article (Kovács, Prohászka 2016: 59-63). A Hungarian soldier, a teacher by profession, sent a postcard to the Hungarian National Museum in Budapest, describing an inscription on a Roman tombstone that the soldiers in his unit found near Smederevo, and inquiring about the possibility to transfer it to Budapest by boat. It is unknown what became of the monument, but given the fact that this inscription has not been published anywhere, it was probably never transported to Budapest and remained in Smederevo, where it was destroyed or reused later for something else.
Đurađ's death, in 1457, possibly as a consequence of poisoning or while trying to escape from the court, and the sole heir to the Serbian throne became Lazar Branković (Спремић 2013: 905-906).

\section{CONCLUSION}

Based on everything we mentioned above, it is possible to conclude that, throughout history, women were perceived in different ways, but often according to preconceived patterns. Even when they belonged to the imperial circles, they could not escape being judged and their origin, as well as the way they arrived at the throne, being questioned. References to women's activities in historical sources often appear in narratives that primarily do not concern women, and were written by men. However, women fought in ingenious ways and managed to overcome the limitations of their rights and a life in a militaristic society, defying preconceived stereotypes, which were often overlooked and forgotten when these women would include Christian values in their life (Herrin 1993: 167-189; James 1997: 123-140).

The label of harlot and a woman's libertine behaviour became, with time, usual patterns of negative attitudes, associated to the primary, instinctive principles in women and often connected to demonic notions. Associating women to demonic beings, most often fairies and witches, was one of the generally accepted models of stereotypes in folk tradition. Besides the fact that there existed ordinary, innocent women who suffered because of these associations, the fear and awe that these mythical beings inspired in people can be linked to one of the oldest fears that men experienced with regard to women, the fear of female generative powers (gynophobia) (Irwin 2007: 13-23). One of the incarnations of this relationship with the fear of female powers was the image of Medusa, who, as a demonic creature, became demystified even during the Roman period. Although a being of demonic nature, but carrying a significant 
apotropaic character, it was accepted in the Christian world, through folk tradition, as a symbol of the triumph of justice, repentance and punishment for the culprits, harmonising pagan religious principles with Christian ones, and linking Medusa's image to two legends from the Braničevo region, those of the sister Jelica and the little girl Nikolina (Milovanović, Anđelković Grašar 2017: 177).

Due to the fear of otherworldly forces and the destructive powers of female demonic creatures, it was believed that during the construction of every important edifice it was necessary to make a sacrifice to these beings, mostly fairies, who would otherwise, during night-time, destroy everything that had been built during the day. In the village of Kostolac we have recorded a legend which is a mixture of the variant of this Balkan motive, present also in the poem "Building the City of Skadar" and the motive from the poem "God Settles All Scores". In the legend we have recorded three brothers were erecting a monastery, but everything that the masons had built during the day, a fairy would "bring down" during the night. In order to appease the fairy, according to her request, the brothers built the youngest of their three sisters into the wall. As folklore was distancing itself from mythology, the act of creation was being transferred from gods to humans. However, the model of creation remained the same and, in order to "copy" the primordial cosmogonic act in all of its segments - the victory of the Creator over the incarnated Chaos, i.e. tearing apart the mythical monster and shaping the world out of its body parts - the institution of the building sacrifice was established (building a human body into the foundations of the future edifice) (Бошковић 2005: 74).

The characters can, thus, be mixed up, their names and names of places forgotten, but the memory of the elements of the poems bearing the basic values remains. Legends as specific folkloric forms can offer a wide range of evidence concerning the sociocultural characteristics of a population and a time period, while folkloric forms enable us to learn more about the beliefs, values and customs of a specific cultural community and reveal the way in which they directed and formed the behaviour and convictions of people. Legends preserve the tradition and the consciousness of identity of a population, and in their core they preserve the memory of real events (Гузина 2011: 83).

As a result of all of the above, we can only imagine what it must have been like for women to withstand a centuries-long heritage of stereotypes and how close they constantly were to being punished, not only for their behaviour, but precisely for the stereotypes through which they were perceived. Although such examples are many in legends, lore and epic poetry, even historical figures could not escape becoming a part of cultural models, and in this case part of the stereotypes, one of the best examples being the Despotess Jerina and, subsequently, Mara Branković as her offspring. These two women were characterised through typical categorisations of lower female deities, particularly fairies and witches. Since many evil deeds were ascribed to Jerina, from constraining the people to forced labour, marrying her daughter to a Turk, to being an intermediary in the blinding of her sons, the folk found an analogy with the actions of witches, evil women of demonic nature, who attack their own male children, and introduce their daughters to the "witch company" (Стамболић 2017: 225-227). On the other hand, in the character of Jerina we can also recognise some attributes of fairies, like the abovementioned demand for sacrifice during the construction of a city. Furthermore, Veselin Čajkanović considers Jerina as possibly the oldest fairy, or Mother Earth, or a cursed girl condemned to wander among ruins for eternity, which explains the fact that, aside from Smederevo, many other city fortresses are named Jerina's City (Чајкановић 1994: 276; Стамболић 2017: 228).

\section{$* * *$}

Arheologija i prirodne nauke (Archaeology and Science) is an Open Access Journal. All articles can be downloaded free of charge and used in 
accordance with the licence Creative Commons

- Attribution-NonCommercial-NoDerivs 3.0

Serbia (https://creativecommons.org/licenses/bync-nd/3.0/rs/.

Časopis Arheologija i prirodne nauke je dostupan u režimu otvorenog pristupa. Članci objavljeni u časopisu mogu se besplatno preuzeti sa sajta i koristiti u skladu sa licencom Creative Commons - Autorstvo-Nekomercijalno-Bez prerada 3.0 Srbija (https://creativecommons.org/licenses/bync-nd/3.0/rs/.

\section{BIBLIOGRAPHY}

\section{Sources:}

\section{ASS Aug. III}

Altmann of Hautvillers, Vitae Helenae, (trans.) P. Dräger, Almann von Hautvillers. Lebensbeschreibung oder eher Predigt von der heiligen Helena, Trier 2007

\section{Aur. Vict. Caes., Epit. De Caes.}

Sexti Aurellii Victoris, Liber de Caesatibus, praecedunt Origo gentis Romanae et Liber de viris illustribus urbis Romae, subsequitur Epitome de Caesaribus, recensuit F. Pichlmayr, Lipsiae 1911.

\section{Euseb. Vita Const.}

De Vita Imp. Constantini, in: Eusebii Pamphili Caesareae Palaestinae Episcopi, Opera omnia quae existant, Tomus II, Paris 1837.

\section{John Eph., HE}

John of Ephesus, Iohannis Ephesini Historiae Ecclesiasticae Pars Tertia, ed. E.W.Brooks, CSCO 106, Scr. Syr. 54-5, Louvain: L.Durbecq, 1935-6, repr. 1952.

John Eph., Lives, PO 17

John of Ephesus, Lives of the Eastern Saints, (ed. and trans.) E. W. Brooks, Patrologia Orientalis 17, Paris 1923,1-307.

\section{Lact. De Mort.}

Lactantius, De mortibus persecutiorum, (eds.) S. Brandt, G. Laubmann, Corpus Scriptorum Ecclesiasticorum Latinorum 1897.

\section{Procop. De bellis}

Procopius, Wars, ed. J.Haury, rev. G.Wirth, $O p$ era, vols 1-2: Bella, Leipzig: Teubner, 1962-3; tr. H.B. Dewing, vols 1-5, Cambridge, Mass.: Loeb, 1914- 40.

Proc. Hist. arc.

Prokopije iz Cezareje, Tajna istorija (Procopius, Historia arcana), (prev.) Albin Vilhar, Predgovor i komentar Radivoj Radić, Beograd 2004.

\section{Theophanes, Chronicle}

The Chronicle of Theophanes Confessor: Byzantine and Near Eastern History AD 284-813. (Trans.) C. Mango, R. Scott, Oxford, 1997.

\section{Literature:}

Antički portret u Jugoslaviji, 1987

Antički portret u Jugoslaviji, (ur.) N. Cambi, I. Popović, Lj. B. Popović, D. Srejović, Narodni muzej Beograd, Muzeji Makedonije Skopje, Arheološki muzej Zagreb, Arheološki muzej Split, Narodni muzej Ljubljana, Beograd 1987.

\section{Allen, P. 1992}

Contemporary Portrayals of the Byzantine Empress Theodora (of AD 527-48), in: Stereotypes of Women in Power: Historical Perspectives and Revisionist Views, (eds.) Barbara Garlick, Suzanne Dixon, Pauline Allen, Greenwood Press, New York, London: 93-104.

\section{Barnes, T. D. 1982}

The New Empire of Diocletian and Constantine, Harvard Uneversity Press: London.

Бојковић, Г. and Ђокић, Н. 2016

Средњовековне иркве и манастири у Браничеву по српским и аустријским пописима из XVIII 
века. Пожаревац: Народни музеј Пожаревац.

(Bojković, G. and Đokić, N. 2016

Srednjovekovne crkve i manastiri u Braničevu po srpskim i austrijskim popisima iz XVIII veka. Požarevac: Narodni muzej Požarevac.)

\section{Бошковић, Л. 2005}

Бог ником дужан не остаје, слојевитост фолклорног текста и ресемантизација мотива, 3борник Матице српске за књижевност и језик, LIII/1-3: 73-82.

(Bošković, L. 2005

Bog nikom dužan ne ostaje, slojevitost folklornog teksta i resemantizacija motiva, Zbornik Matice srpske za književnost i jezik, LIII/1-3: 73-82.)

\section{Brubaker, L. 1997}

Memories of Helena: Patterns in Imperial Female Matronage in the Fourth andFifth Centuries, in: Women, Men and Eunuchs. Gender in Byzantium, (ed.) Liz James, Routledge, London, New York: 52-75.

\section{Brubaker, L. 2004}

Sex, Lies and Textuality: The Secred History of Prokopios and the Rhetoric of Gender in Sixth-Century Byzantium, in: Gender in the Early Medieval World: East and West, 300-900, (eds.) L. Brubaker, J. M. H. Smith, Cambridge University Press, Cambridge: 83-101.

\section{Cameron, A. 1976}

Circus Factions, Blues and Greens at Rome and Byzantium, Clarendon Press: Oxford.

\section{Coon, L. L. 1997}

Sacred Fictions, Holy Women and Hagiography in Late Antiquity, University of Pennsylvania Press: Philadelphia.

Цветковић, С. 2009

Античка пластика Смедревске тврђаве-преглед досадашњих истраживања, Смедеревски зборник 2: 29-43.
(Cvetković, S. 2009

Antička plastika Smedrevske tvrđave-pregled dosadašnjih istraživanja, Smederevski zbornik 2: 29-43.)

\section{Чајкановић, В. 1994}

Стара српска религија и митологија, Београд:

Српска књижевна задруга.

(Čajkanović, V. 1994

Stara srpska religija i mitologija, Beograd: Srpska književna zadruga.)

\section{Daube, D. 1967}

The Marriage of Justinian and Theodora: Legal and Theological Reflections, Catholic University Law Review 16: 380-399.

\section{Drijvers, J. W. 1992}

Helena Augusta: the mother of Constantine the Great, and the legend of her finding of the True Cross, Brill: Leiden.

\section{Drijvers, J. W. 1993}

Helena Augusta: Exemplary Christian Empress, Studia Patristica_24, Louvain: 85-90.

Ђокић, Д., and Јацановић Д. 1992

Топографска грађа Стига, Viminacivm 7: 61-110. (Đokić, D., and Jacanović D. 1992

Topografska građa Stiga, Viminacivm 7: 61-110.)

\section{Evans, J. A. 2002}

The Empress Theodora: Partner of Justinian, The University of Texas Press: Austin.

\section{Evans, J. A 2011}

The Power Game in Byzantium: Antonina and the Empress Theodora, A\&C Black.

\section{Freisenbruch, A. 2011}

Caesars' Wives: Sex, Power, and Politics in the Roman Empire, Simon and Schuster: New York. 


\section{Garland, L. 1999}

Byzantine empresses: women and power in Byzantium, AD 527-1204, London: Routledge.

\section{Grahn, J. 1993}

Blood, Bread, and Roses: How Menstruation Created the World, Boston: Beacon Press.

\section{Гузина, Н. 2011}

Директивна снага културних модела: улога и значај на примеру анализе легенди о градњи као специфичних фолклорних форми, Речи, часопис за језик, књижевност и културолошке cmyдије 4: 79-92.

(Guzina, N. 2011

Direktivna snaga kulturnih modela: uloga i značaj na primeru analize legendi o gradnji kao specifičnih folklornih formi, Reči, časopis za jezik, književnost i kulturološke studije 4: 79-92.)

\section{Herrin, J. 1993}

In Search of Byzantine Women, Three avenues of Approach, in: Images of Women in Antiquity, (eds.) A. Cameron, A. Kuhrt, Routledge, London 1993 ( $2^{\text {nd }}$ edition): $167-189$.

\section{Herrin, J. 2001}

Women in Purple. Rulers of Medieval Byzantium, Princeton University Press: Princeton, New Jersey.

\section{Holum K. G. 1982}

Theodosian Empresses: Women and Imperial Domination in Late Antiquity, University of California Press: Berkeley, Los Angeles.

\section{Irwin, E. 2007}

The Invention of Virginity on Olympus, in: Virginity Revisited: Configurations of the Unpossessed Body, (eds.) B. MacLachlan, J. Fletcher, University of Toronto Press, Toronto, Buffalo, London: 13-23.

\section{James, L. 1997}

Goddess, Whore, Wife or Slave: Will the Real
Byzantine Empress Please Stand Up?, in: Queens and Queenship in Mediaeval Europe, Proceedings of a Conference held at King's College London April 1995, (ed.) A. J. Duggan, The Boydell Press, Woodbridge: 123-140.

\section{James, L. 2001}

Empresses and Power in Early Byzantium, Leicester University Press: London, New York.

\section{Јовић, Д. 2014}

Ја како знам, тако ћу да причам: Поетика казивања предања на примерима варијаната о манастиру Брадачи, у Сувајџић, Б., Златковић, Б. (ур.) Промишьвања традичије. Фолклорна и литерарна истраживана. Зборник радова посвећен Мирјани Дрндарски и Ненаду Љубинковићу. Београд: Институт за књижевност и уметност: 259-279.

(Jović, D. 2014

Ja kako znam, tako ću da pričam: Poetika kazivanja predanja na primerima varijanata o manastiru Bradači, u Suvajdžić, B., Zlatković, B. (ur.) Promišljanja tradicije. Folklorna i literarna istraživanja. Zbornik radova posvećen Mirjani Drndarski $i$ Nenadu Ljubinkoviću. Beograd: Institut za književnost i umetnost: 259-279.)

\section{Коњик, И. 2006}

Представе о Грцима у Вуковом корпусу епских песама, Гласник Етнографског института CAHY LIV: 57-67.

(Konjik, I. 2006

Predstave o Grcima u Vukovom korpusu epskih pesama, Glasnik Etnografskog instituta SANU LIV: 57-67..)

\section{Koumarianou, M. 2007}

Cursed sites and cursed practices, treasure hunting at haunted places: A case study from Greece, Glasnik Etnografskog instituta SANU, 55/1: 171192. 
Kovács, P., Prohászka, P. 2016

A Roman Funerary Inscription from Smederevo, Старинар LXVI: 59-63.

(Kovács, P., Prohászka, P. 2016

A Roman Funerary Inscription from Smederevo, Starinar LXVI: 59-63.)

Lenski, N. 2012

The Reign of Constantine, in: The Cambridge Companion to the Age of Constantine, (ed.) N. Lenski, Cambridge University Press, New York: 59-90.

\section{McClanan, A. 1996}

The Empress Theodora and the Tradition of Women's Patronage in the Early Byzantine Empire, in: The Cultural Patronage of Medieval Women, (ed.) J. H. McCash, University of Georgia Press: 50-72.

McClanan, A. 2002

Representations of Early Byzantine Empresses: Image and Empire, New York.

Milovanović, B. and Anđelković Grašar, J. 2017

Female Power That Protects: Examples of the Apotropaic and Decorative Functions of the Medusa in Roman Visual Culture from the Territory of the Central Balkans, Starinar 67: 167-182.

Миљковић, E. and Крстић, А. 2007

Браничево у XV веку. Историјско-географска студија. Пожаревац: Народни музеј Пожаревац. (Miljković, E. and Krstić, A. 2007

Braničevo u XV veku. Istorijsko-geografska studija. Požarevac: Narodni muzej Požarevac.)

\section{Мирковић, П. 2012}

Србски манастир Рукумија. Манастир Рукумија.

(Mirković, P. 2012

Srbski manastir Rukumija. Manastir Rukumija.)

Павловић, Л. 1965

Култови лища код Срба и Македонаџуа.
Смедерево: Народни музеј Смедерево.

(Pavlović, L. 1965

Kultovi lica kod Srba i Makedonaca. Smederevo: Narodni muzej Smederevo.)

\section{Поповић, П. 1931}

Архитектура, у Поповић, П. (ур), Споменииа петстогодишнице Смедеревскога града Деспота Ђурђа Бранковића. Београд: Државна штампарија у Београду: 31-134.

(Popović, P. 1931

Arhitektura, u Popović, P. (ur), Spomenica petstogodišnjice Smederevskoga grada Despota Đurđa Brankovića. Beograd: Državna štamparija u Beogradu: 31-134.)

\section{Поповић, А. В. 2010}

Император Галерије и Felix Romuliana у светлу писаних извора, Ниш и Византија VIII, Ниш: 479-489.

(Popović, A. V. 2010

Imperator Galerije i Felix Romuliana u svetlu pisanih izvora, Niš i Vizantija VIII, Niš: 479-489.)

Радовановић, Д. 1997

Археолошка налазишта са сакралним садржајем на подручју Подунавског и Браничевског округа, Споменици Смедеревља и Браничева 1: 235-256.

(Radovanović, D. 1997

Arheološka nalazišta sa sakralnim sadržajem na području Podunavskog i Braničevskog okruga, Spomenici Smederevlja i Braničeva 1: 235-256.)

Roymans, N., Gerritsen, F., Van der Heijden, C., Bosma, K. and Kolen, J. 2009

Landscape Biography as Research Strategy: The Case of the South Netherlands Project, Landscape Research 34/ 3: 337-359.

Спасић, Д. 1996

Пример археолошког трага у етнографској грађи из околине Пожаревца, Гласник Српског археолошког друштва 12: 219-226. 
(Spasić, D. 1996

Primer arheološkog traga u etnografskoj građi iz okoline Požarevca, Glasnik Srpskog arheološkog društva 12: 219-226.)

\section{Спасић, Д. 1998}

Светиња манастира Нимника - од легенде до мита, Гласник Српског археолошког друштва 14: 315-325.

(Spasić, D. 1998

Svetinja manastira Nimnika - od legende do mita, Glasnik Srpskog arheološkog društva 14: 315-325.)

\section{Спремић, М. 2013}

Деспот Лазар Бранковић, Зборник радова Византолошког института L: 899-912.

(Spremić, M. 2013

Despot Lazar Branković, Zbornik radova Vizantološkog instituta L: 899-912.)

\section{Стамболић, И. А. 2017}

Лик Маре Бранковић - између властелинског и демонског, Зборник за језике и књижевности Филозофског факултета у Новом Саду 7: 217232.

(Stambolić, I. A. 2017

Lik Mare Branković - između vlastelinskog i demonskog, Zbornik za jezike i književnosti Filozofskog fakulteta u Novom Sadu 7: 217-232.)

\section{Stojaković, M. 1987}

Braničevski tefter: Poimenični popis pokrajine Braničevo iz 1467. godine. Beograd: Istorijski institut.

\section{Valeva, J. 2009}

Empresses of the fourth and fifth centuries: Imperial and religious iconographies, Ниш и Византија VII (ур. Миша Ракоција), НКЦ Ниш: 67-76.

\section{Vasiliev, A. A. 1950}

Justin the First: An Introduction to the Epoch of Justinian, Cambridge, Mass.: Harvard University Press.

\section{Веселић, J. 1861}

Опис монастира у Србији, Београд: Књигопечатија А. Андрића.

(Veselić, J. 1861

Opis monastira u Srbiji, Beograd: Knjigopečatija A. Andrića.)

\section{Voss, J. A. 1987}

Antiquity imagined: Cultural values in archaeological folkore, Foklore, 98/1: 80-90.

\section{Зечевић, С. 1966}

Таласони - митска бића заштитници грађевина и закопаног блага, Гласник Етнографског музеја у Београду, 28-29 (1965-1966): 287-296. (Zečević, S. 1966

Talasoni - mitska bića zaštitnici građevina i zakopanog blaga, Glasnik Etnografskog muzeja u Beogradu, 28-29 (1965-1966): 287-296.)

\section{Зечевић, С. 1973}

Заветина у североисточној Србији, Гласник Етнографског музеја у Београду 36: 43-67.

(Zečević, S. 1973

Zavetina u severoistočnoj Srbiji, Glasnik Etnografskog muzeja u Beogradu 36: 43-67.)

\section{Зечевић, С. 1981}

Митска бића српских предања. Београд: Вук Караџић.

(Zečević, S. 1981

Mitska bića srpskih predanja. Beograd: Vuk Karadžić.)

\section{Зечевић, С. 1993}

Нека веровања из традиције становништва приобалних насеља доњег Дунава, Гласник Етнографског музеја у Београду 57: 257-273.

(Zečević, S. 1993

Neka verovanja iz tradicije stanovništva priobalnih naselja donjeg Dunava, Glasnik Etnografskog muzeja u Beogradu 57: 257-273.) 
Живић, М. 2010

Уметничка остварења у царској палати, у: Felix Romuliana - Гамзиград, (ур.) Ивана Поповић, Београд: 107-140.

(Živić, M. 2010

Umetnička ostvarenja u carskoj palati, u: Felix Romuliana - Gamzigrad, (ur.) Ivana Popović, Beograd: 107-140.)

\section{REZIME STEREOTIPI KAO PROTOTIPI U PERCEPCIJI ŽENA: NEKOLIKO PRIMERA IZ ISTORIJE I NARODNE TRADICIJE}

\section{KLJUČNE REČI: STEREOTIP, ŽENA, CARICA, KURTIZANA, VEŠTICA, VILA, DEMONSKO BIĆE, ISTORIJA, LEGENDA, NARODNA TRADICIJA.}

Stereotipi koji prate žene već vekovima su uobičajeni i odomaćeni u patrijarhalnim društvima, kakvo je i naše. Osuđivanja i tzv. „etiketiranja“ nisu zaobilazili ni dame carskog kruga, a posebno su bile osuđene one žene, čije se ponašanje ili poreklo, kosilo sa hrišćanskom etikom.

Ranohrišćanske carice najčešće su u izvorima opisivane kao bludnice i prostitutke, neznatnog porekla, koje su moralnu sliku sticale udajom za cara i aktivnostima vezanim za crkvu, što je rezultiralo uzornim hrišćanskim ponašanjem i izmenjenom percepcijom društva prema njima. Ova vrsta stereotipa nije zaobišla ni najpoznatiju hrišćansku caricu, majku Konstantina Velikog, koja je postala uzor svim dobrim, budućim hrišćanskim caricama, i ženama uopšte. Ovi narativi uglavnom su pisani od strane muškaraca, a slika o ženama, kakva je stvorena i o carici Teodori u Prokopijevoj Tajnoj istoriji, teško se menjala, a često ostajala prisutna u sveti ljudi vekovima.

Sa druge strane, narodna tradicija pokazuje istu moć stereotipa, ovoga puta onih koji nisu zapisani, već usmeno prenošeni generacijama i često vezani za legendu, a ponekad opevani u narodnoj poeziji. Mnoge žene koje u svojim sredinama nisu bile prihvaćene ili su svojim ponašanjem rušile uvrežene modele ponašanja u strogo koncipiranom patrijarhalnom društvu bile su povezivane sa demonskim bićima, i to najčešće sa vilama i vešticama. Zato i ne čudi da je u dva primera lik Meduze, kao jednog od takvih demonskih bića, uzet za asocijaciju na dve žene za koje su vezane legende o kažnjavanju i žrtvi, Jelicu i Nikoliju, te da je usaglašavanjem paganskih sa hrišćanskim moralnim načelima i ovaj demonski lik duboko humanizovan u odnosu na njegov inicijalni izgled.

Zastrašujuće ženske demonske moći u narodu su izazivale strahopoštovanje, a verovanje u vile i veštice, bilo je sveprisutno, do te mere, da je bilo koja žena iole drugačijeg ponašanja mogla da bude smatrana upravo ovakvim bićem. Narod je verovao u čin prinošenja žrtve vilama tokom graditeljskih poduhvata, što je zabeleženo u više legendi i narodnih pesama. Jedna od najpoznatijih je i ona o građenju Smedereva, zbog čega je vizantijska carica Irina Kantakuzin, u narodu prozvana prokleta Jerina. Zbog prisilnog rada i velike žrtve koju je narod podnosio radi ovog građevinskog poduhvata, Jerina je bila smatrana vilom, dok su osobine veštica pripisane i njoj ali i njenoj ćerki Mari Branković, najviše zbog toga što su ih smatrali odgovorinim za oslepljenje Grgura i Stefana, te i propast cele dinastije Brankovića.

Stereotipi o percepciji žena, vekovima su stvarani na mitološkim, istorijskim i kulturološkim obrascima, a razvijali su se u pogodnoj klimi hrišćanske moralnosti i patrijarhalne sredine. Čak i kada je ponašanje žene bilo uzorno, ona je mogla biti osuđena iz bilo kojih pobuda, najčešće jer je bila okarakterisana kao strankinja, u zemlji, društvu, porodici i zbog toga je morala da bude kažnjena. 